\title{
Doğa Yürüyüşçülerinin Öz-Liderliklerinde Duygusal Zekânın Rolü
}

The Role of Emotional Intelligence on the Self-Leadership of Trekkers

\author{
Mehmet ERTAŞ*, Mehmet Ali IŞIK** \\ *(Sorumlu Yazar) Dr., Pamukkale Üniversitesi Turizm Fakültesi, Kınıklı Kampüsü, Pamukkale, Denizli, 20160. \\ E-Posta: mehmetertas@pau.edu.tr \\ ORCID: 0000-0003-4396-5104 \\ ** Öğretmen, MEB Torbalı Çetineller Ortaokulu, Torbalı Mahallesi 5027 Sokak No: 22 Torbalı, İzmir, 35860. \\ E-Posta: isik.mali@gmail.com \\ ORCID: 0000-0002-7307-1729
}

\section{MAKALE BILGILERI}

Makale işlem bilgileri:

Gönderilme tarihi: 30 Mart 2021

Birinci düzeltme: 7 Temmuz 2021

İkinci düzeltme: 9 A ğustos 2021

Üçüncü düzeltme: 6 Ekim 2021

Kabul: 12 Ekim 2021

Anahtar sözcükler: Öz-liderlik, Duygusal zekâ, Doğa yürüyüşü, İyi oluş, Başarilı performans.

\section{ARTICLE INFO}

Article history:

Submitted: 30 March 2021

Resubmitted: 7 July 2021

Resubmitted: 9 August 2021

Resubmitted: 6 October 2021

Accepted: 12 October 2021

Key words: Self-leadership, Emotional intelligence, Trekking, wellbeing,

Successful performance.

\section{ÖZ}

Bu çalışmanın amacı, doğa yürüyüşlerinde liderlik yapan bireylerin öz-liderlikleri üzerinde duygusal zekânın rolünü ortaya çıkarmaktır. Veriler doğa yürüyüșlerinde liderlik yapan bireylerden çevrimiçi anket yoluyla toplanmıștır. Toplamda kullanılabilir 239 anket elde edilmiștir. Çalıșmada, ölçeklerin geçerliklerini ve güvenirliklerini ortaya çıkarmak amacıyla açıklayıcı faktör, değişkenler arasındaki ilişkiyi ortaya koymak için korelasyon ve duygusal zekânın öz-liderlik üzerindeki etkisini belirlemek amacıyla regresyon analizi gibi nicel analizler uygulanmıstır. Analizler sonucunda duygusal zekânın doğa yürüyüșcülerinin öz-liderlikleri üzerinde etkili olduğu sonucuna ulaşılmıştır. Öz-liderlik üzerinde duygusal zekânın iyi oluş ve sosyallik değişkenleri pozitif, öz-kontrol değişkeni negatif yönlü etkilidir. Doğa yürüyüşçülerinin yüksek motivasyona sahip, çevre ile uyumlu ve stres ile baș edebilen kişiler olmaları öz-liderlikleri üzerinde pozitif etkiye sahiptir. Ayrıca çalışma, dağcılık kulüplerine ve doğa yürüyüşçülerine duygusal zekâ ve öz-liderlik konularında yol gösterici öneriler sunmaktadır.

\section{GiRiş}

Günlük hayatımızda bir arkadaş grubuyla sohbet ederken, bir yolculuk esnasında veya bir etkinlikte birçok duyguyu birlikte yaşarız. Duygular aynı zamanda insan doğasının ayrılmaz bir parçası ve davranış motivasyonudur ( $\mathrm{Li}, \mathrm{Lu}$ ve
Wang 2009). Serbest zaman aktiviteleri de benzer şekilde kişilere birçok duygunun yaşandığ 1 ortamlar sunmaktadır. Bu aktiviteler sırasında duyguları yönetebilmek, sosyal ilişkiler için empati kurabilmek ve sorumluluk duygusu taşıyabilmek için kişilerin duygusal zekâları oldukça önemlidir (Maamari ve Majdalani 2017). 
Duygusal zekânın kişilerin öz-liderlikleri üzerinde olumlu etkileri olduğu çeşitli çalışmalarla kanıtlanmıştır. Kişilerin liderliklerinde etkili ekip etkileşimi ve üretkenliği için duygusal zekânın önemli olduğu öne sürülmektedir (Prati, Douglas, Ferris, Ammeter ve Buckley 2003). George (2000), duygusal zekâsı yüksek liderlerin, ekip üyeleriyle çalışmalarını ve üyeleri motive etmelerini sağlayacak şekilde duyguları tanıyabileceklerini, değerlendirebileceklerini, tahmin edebileceklerini ve yönetebileceklerini belirtmektedir. Ayrıca duygusal zekâsı yüksek liderlerin iletişimleri, performansları, istikrarı, sosyal ortam ilişkileri, karar verme, bağlılık ve verimlilikteki etkinliği ve sorumluluk duyguları daha iyidir (Maamari ve Majdalani 2017). Bununla birlikte alan dışı aktivitelerde liderlik yapan bireylerin duygusal zekâ ve doğa deneyimleri arasındaki ilişkileri inceleyen Hayashi ve Ewert (2006), çalışmaları sonucunda doğa deneyimine sahip liderlerin daha yüksek duygusal zekâya sahip olduğunu saptamıştır. Araştırmacılar doğada bulunmanın duygusal zekânın iletişim özelliğine olumlu bir katkısı olduğunu da ortaya çıkarmıştır (Hayashi ve Ewert 2006).

Alanyazın incelendiğinde öz-liderlik ve duygusal zekâ ilişkisi daha çok yönetim ve organizasyon çalışmaları üzerine yoğunlaştığı görülmektedir (Maamari ve Majdalani 2017; Issah 2018; Lee ve Chelladurai 2018; Abdullahi, Anarfo ve Anyigba 2020). Bu çalışmalar işletme bazında duygusal zekânın yöneticilerin liderlikleri üzerindeki etkilerine örgüt iklimi ve yönetici tarzı çerçevesinden odaklanmaktadır (Maamari ve Majdalani 2017; Abdullahi vd., 2020). Bu güncel çalışma ise serbest zaman aktivitelerinde lider olarak yer alan bireylerin duygusal zekâlarının öz-liderliklerini ne şekilde etkilediğini ortaya koymaktadır. Bu çalışmada örneklem olarak serbest zaman aktivitelerinde liderlik yapan kişilerin seçilmesindeki amaç serbest zaman etkinliklerine veya fiziksel aktivitelere katılan bireylerin liderlikleri ve duygusal zekâları arasındaki ilişki ile ilgili çalışmaların kısıtlı olmasıdır (Hayashi ve Ewert 2006; Li vd. 2009; Acebes-Sanchez, Diez-Vega, Esteban-Gonzalo ve Rodriguez-Romo 2019).
Duygusal zekâ ve öz-liderlik arasındaki ilişkinin incelenmesindeki bir diğer neden duygusal zekânın liderler için oldukça önemli olmasıdır (Prati vd. 2003; Maamari ve Majdalani 2017; Lee ve Chelladurai 2018). Ancak doğa yürüyüşlerinde liderlik yapan bireylerin de bu aktivitelerde öz-liderlik özelliklerini sergileme noktasında duygusal zekâlarının rolünü ortaya koyan çalışmaya rastlanmamıştır. Bu güncel çalışmada ise alan dışı rekreatif aktivitelerdeki kişilerin öz-liderliklerinde duygusal zekânın etkili bir faktör olacağı çalışmanın bir sonucu olarak varsayılmaktadır. Bu nedenle bu problemin ortaya çıkarılması rekreasyon ve serbest zaman literatüründe yer alan önemli bir boşluğu dolduracağ1 düşünülmektedir. Bu doğrultuda çalışma, serbest zamanlarında doğa yürüyüşlerine katılan ve bu aktivitelerdeki gruplara aktif olarak liderlik yapan bireylerin öz-liderlikleri ile duygusal zekâları arasındaki ilişkiyi ortaya koymayı amaçlamaktadir.

\section{DUYGUSAL ZEKÂ VE ÖZ-LIDERLIK}

Duygusal zekâ, kişinin kendi ve başkalarının duygu ve düşüncelerini izleme, aralarında ayrım yapma ve bu bilgiyi kişinin düşüncelerine ve eylemlerine rehberlik etmek için kullanma becerisini içeren sosyal zekânın alt kümesi olarak tanımlanmaktadır (Salovey ve Mayer 1990; Mayer ve Salovey 1997). Feldman'a (1999) göre duygusal zekâ, temel ve üst düzey becerilerden oluşmaktadır. Temel beceriler, kendini tanımayı, kontrolü sürdürmeyi, başkalarını doğru şekilde alg1lamayı ve esnek iletişim kurmayı içermektedir. Üst düzey beceriler, sorumluluk almayı, seçimler yapmayı, bir vizyonu benimsemeyi, cesarete sahip olmayı ve kararlılık göstermeyi içermektedir. Petrides ve Furnham (2000) duygusal zekânın özellik ve bilgi işlem süreci olarak iki farklı boyutu olduğunu belirtmektedir. Özellikli duygusal zekâ boyutu, yeteneklerle ilgili (örneğin, duyguları tanımlayabilme, ifade edebilme ve etiketleyebilme) bilgi işleme duygusal zekâ boyutunun aksine davranıştaki (empati, atılganlık, iyimserlik gibi belirli özelliklerde veya davranışlarda kendini gösteren) durumlar arası tutarlılıklarla 
ilgilidir (Petrides ve Furnham 2000; Deniz, Özer ve Işık 2013).

Salovey ve Mayer (1990) duygusal zekânın üç ayrı bileşenden bir araya geldiğini belirtmektedir. Bunlar; duyguların değerlendirilmesi ve ifadesi, duyguların düzenlenmesi ve duygusal bilginin düşünme ve eylemde kullanılmasıdır. Duyguların değerlendirilmesi ve ifadesi; duygusal zekânın altında yatan süreçler, duygulanımsal bilgi algısal sisteme ilk girdiğinde başlatılır ve duyguların doğru bir şekilde değerlendirilmesine izin verir. Duygularm düzenlenmesi; insanlar ruh hallerini hem doğrudan hem de yansitıcı düzeyde yaşarlar. Duygusal bilginin düşünme ve eylemde kullanılması; duygu durumları sistematik olarak problem çözmede bazı bileşenleri etkiler (Salovey ve Mayer 1990).

Mayer ve Salovey (1997) ayrica duygusal zekânın bilişsel bileşenlerine daha fazla vurgu yapan ve duygusal zekâyı entelektüel ve duygusal büyüme potansiyeli açısından kavramsallaştıran, gözden geçirilmiş bir duygusal zekâ modeli formüle etmiştir. Gözden geçirilmiş bu model duygusal zekânın dört bileşeninden oluşmaktadır: Duygu algilama, değerlendirme ve ifade; düşünmenin duygusal kolaylaştırılması; duygusal bilgiyi anlamak, analiz etmek ve kullanmak; duygusal ve entelektüel büyümeyi ilerletmek için duyguların yansitıcı düzenlemesini yapmak. Anlaşılacağı üzere yazarlar duygusal zekâyı ilk olarak üç bileşen, daha sonra bunu geliştirerek dört bileşen üzerinden açıklamıştır. Bu bileşenler ayrıca duygusal zekânın detaylı bir şekilde açıklanmasına yardımcı olmaktadır. Sonuç olarak duygusal zekâ ile ilgili beceriler geliştirmiş kişiler, kendi duygularını anlamakta ve ifade etmekte, başkalarının duygularını tanımakta, duygulanımlarını düzenlemekte ve uyumsal davranışları motive etmek için ruh hallerini ve duygularını kullanmaktadır (Salovey ve Mayer 1990; Mayer ve Salovey 1997).

Petrides (2009) ayrıca duygusal zekânın duygusallık, kendini kontrol etme, sosyallik ve refah olarak dört temel boyutunun olduğunu belirtmektedir. Duygusallik; bireyler kendilerinin ve başkalarının duygularıyla temas halindedir. Duygusallık boyutu düşük olan bireyler iç duy- gusal durumlarını tanımakta ve duygularını başkalarına ifade etmekte zorlanır. Bu durum da daha az ödüllendirici kişisel ilişkilere yol açar. Kendini kontrol etme; kendine kontrol etme düzeyi yüksek olan kişiler diş baskılar ve stresi düzenlemede iyidirler. Sosyallik; yüksek sosyallik düzeyinde olanlar sosyal etkileşimde daha iyidir. İyi dinleyicidirler, başkalarıyla net ve kendinden emin bir şekilde iletişim kurarlar. Refah; yüksek refah düzeyine sahip olanlar kendilerini olumlu, mutlu ve tatmin olmuş hissederler. Düşük olanlar ise yaşamları hakkında hayal kırıklığına uğrama eğilimindedir.

Duygusal zekâ ve öz-liderlik kavramları birbirleriyle karşıllklı etkileşim halindedir (D'Intino, Goldsby, Hougton ve Neck 2007; Chan ve Mallett 2011). Duygularını kontrol edebilen, duygusal zekâsı yüksek olan kişiler, kendilerini yönetmede de daha başarılıdır. Aynı zamanda kendini gözlemleme, işaret etme, hedef belirleme ve ödüllendirme gibi öz-liderlik becerileri, insanların duygusal olarak daha zeki olmalarına yardımcı olmak için yararlıdır. Başka bir deyişle duygusal zekâya sahip olunması insanları daha iyi öz-liderler haline getirir ve öz-liderlik teknikleri insanların duygusal zekâlarını geliştirmelerine yardımcı olur (D'Intino vd. 2007).

Öz-liderlik, üç temel strateji boyutundan oluşmaktadır: (1) davranış odaklı stratejiler (kendine hedef belirleme, kendini ödüllendirme, kendini cezalandırma, kendini gözlemleme, kendini kurtarma), (2) doğal ödül stratejileri (içsel motivasyon) ve (3) yapıcı düşünce modeli stratejileri (başarılı performansı görselleştirme, kendi kendine konuşma, inançları ve varsayımları değerlendirme) (Houghton ve Neck, 2002; Furtner, Rauthmann ve Sachse 2010; Konan ve Atik, 2015). Davranış odaklı stratejiler, bireylerin liderlik tarzlarındaki bireysel farkındalıklarını arttırma ve daha kolay bir şekilde kendi davranışlarını denetleme ile ilgilidir. Doğal ödül stratejileri, adından da anlaşılacağı üzerine ödüller üzerine kuruludur. Bu stratejiler bireylerin motivasyonlarını arttırarak işlerine daha kolay odaklanmalarını sağlamaktadır. Son olarak yapıcı düşünce modeli stratejileri ise bireylerin gelecek hedeflerini gerçekleştirmek ve sürdürülebilirliğini sağ- 
lamak amacıyla ortaya çıkan stratejilerdir. Bu stratejilerle birey negatif düşüncelerini içsel konuşma aracıllğıyla pozitife dönüştürebilmektedir (Houghton ve Neck, 2002; Konan ve Atik, 2015).

Duygusal zekâ serbest zaman aktivitesi liderliğinde de önemlidir (Hayashi ve Ewert 2006; Acebes-Sanchez vd. 2019). Serbest zaman aktivitesi, deneyimsel eğitim içinde bireyleri/grupları rekreasyon veya eğitim, öğretim becerileri, problem çözme, güvenliğin sağlanması ve karar verme gibi durumlar için kasıtlı olarak etkinliğe götürmeyi içeren bir alandır. Aktivite, bireyin veya grubun amaç ve hedeflerini belirlemesine yardımcı olma; bu hedeflere ulaşmak için belirli eylemlerden yararlanma; öğrenme fırsatları yaratma; yeni veya daha az deneyimli alan dışı katılımcıları ve liderleri eğitme gibi eylemleri içermektedir (Hayashi ve Ewert 2006). Bu nedenlerle duygusal zekâ potansiyel olarak etkili liderleri belirlemek ve etkili liderlik becerileri geliştirmek için giderek daha görünür bir yapı haline gelmiştir. Yüksek düzeyde duygusal zekâya sahip liderler, kişilerin duygusal durumunu dikkatlice gözden geçirebilir, kişileri anlayabilir ve kişilerarası ilişkinin kalitesine katkıda bulunarak uygun duyguları kararlaştırıp ifade edebilir. Diğer taraftan düşük duygusal zekâya sahip liderler ise kişilerarası becerilerde, güvenilir ve ilham verici ilişkilerde sıkıntı yaşayabilirler (Chan ve Mallett 2011).

\section{YÖNTEM}

Çalışmada üç bölümden oluşan tam yapıland1rılmış soru formu ile veriler toplanmıştır. Soru formunun birinci bölümü duygusal zekâ ölçeği, ikinci bölümü öz-liderlik ölçeği ve üçüncü bölümü katılımcıların temel demografik özelliklerine ilişkin sorular oluşturmaktadır. Bu çalışma, Pamukkale Üniversitesi Sosyal ve Beşeri Bilimler Araştırma ve Yayın Etiği Kurulunun 3 Şubat 2021 tarihli E-93803232-622.02-13544 sayılı etik kurul kararı çerçevesinde yürütülmüştür.

\section{Duygusal Zekâ Özelliği Ölçeği}

Çalışmada duygusal zekâ özelliği ölçeğinin kısa formu kullanılmıştır. Bu ölçeğin uzun formu ilk olarak Schutte, Malouff, Hall, Haggerty, Cooper, Golden ve Dornheim (1998) tarafından 33 ifade ile oluşturulmuştur. Araştırmacılar ölçeği geliştirirken Salovey ve Mayer'in (1990) duygusal zekâ modelini temel almışlardır. Daha sonra Petrides ve Furnham (2000) ölçeğe kişisel karakter özelliğini ekleyerek duygusal zekâ ölçeğinin 30 ifadeli kısa formunu geliştirmiştir. Bu ölçeğin Türkçe geçerlik ve güvenirliği ise Deniz ve arkadaşları (2013) tarafından sağlanmıştır. Ölçeğin Türkçe kısa formu 20 ifadeden oluşmaktadır. Bu ifadelerin 10 tanesi ters ifadelerden oluşmaktadır. Duygusal zekâ özelliği ölçeği yedili Likert ölçeği ile kullanılmıştır. Ancak Barbuto ve Burbach (2006) göre duygusal zekâ ölçeği beşli Likert ölçeği ile de kullanılabilmektedir. Ayrıca çalışmada kullanılan diğer ölçek de beşli Likert ölçeğinde olduğundan çalışmada duygusal zekâ özelliği ölçeği beşli Likert (5=Kesinlikle katılıyorum, 1=Kesinlikle katılmıyorum) olarak kullanılmıştır. Deniz ve arkadaşları (2013) ölçeği iyi oluş, öz-kontrolduygusallık ve sosyallik alt boyutlarından oluşan 16 ifadeli olarak ortaya çıkarmıştır. Ayrıca toplam duygusal zekâyı ölçen dört ifade vardır. Böylece toplamda 20 ifade ile duygusal zekâ özelliği ölçeğinin Türkçe güvenirlik ve geçerliği sağlanmıştır.

\section{Öz-Liderlik Ölçeği}

Öz-liderlik ölçeği 35 ifade ile Houghton ve Neck (2002) tarafından geliştirilmiştir. Araştırmacılar ölçeği daha önce geliştirilen öz-liderlik ölçeklerini derleyerek oluşturmuşlardır. Ölçekte dokuz boyut vardır. Bunlar; hedef belirleme (beş ifade), kendini ödüllendirme (üç ifade), kendini cezalandırma (dört ifade), kendini gözleme, (dört ifade) hatırlatıcılar belirleme (iki ifade), doğal ödüller üzerinde düşünceyi odaklama (beş ifade), başarılı performansı hayal etme (beş ifade), kendi kendine konuşma (üç ifade), düşünceleri değerlendirme (dört ifade). Ölçeğin Türkçe geçerlik ve güvenirliği Konan ve Atik (2015) tarafından gerçekleştirilmiştir. Bu güncel çalışmada da ölçek Türkçe geliştirildiği ifadelerle kullanılmıştır. Öz-liderlik ölçeği beşli Likert ölçeğindedir (5: Her zaman, 4: Çoğu Zaman, 3: Ara Sıra, 2. Nadiren, 1: Hiçbir zaman). 


\section{Veri Toplama Yöntemi ve Analizi}

Bu güncel çalışmada örneklem doğa yürüyüşü liderlerinden oluşmaktadır. Diğer rekreatif gruplarda (bisiklet, motosiklet, kaya tırmanışı vb.) liderlik yapan bireyler göz ardı edilmiştir. Çalışmanın evreninin sınırlarını belirlemek amacıyla diğer rekreatif gruplar çalışmaya eklenmemiştir ve bu durum çalışmanın bir sınırlılığını oluşturmaktadır.

Çalışmada veriler çevrimiçi formlar aracılığıyla toplanmıştır. Öncelikle aktif olarak doğa yürüyüşleri gruplarına liderlik yapan kişilere sosyal medya üzerinden ulaşılmıştır. Bu kişilerle sosyal medya üzerinden direkt mesaj yöntemiyle iletişim kurulmuştur. İlk olarak doğa yürüyüşlerinde liderlik yapıp yapmadıkları sorulmuştur. Liderlik yaptığını belirten kişilere çalışmanın amacı ve yazarları paylaşılmış, çalışmaya katılıp katılmayacakları sorulmuştur. Sosyal medya üzerinden mesajlaşma kısmında çalışmaya katılacaklarını belirten kişilere anket formu gönderilmiştir. Ayrıca bu kişiler doğa sporları kulüplerine üye olduklarından kendilerinden anketi grup içinde liderlik yapan diğer kişilerle de paylaşmaları istenmiştir. Doğa yürüyüşleri liderlerine sosyal medya üzerinden yaklaşık 850 mesaj atılmıştır. Hızlı bir şekilde daha fazla kişiye ulaşmak amacıyla veriler sosyal medya araçları üzerinden toplanmıştır. Bu doğrultuda 16 Ocak 202002 Aralık 2020 tarihleri arasinda toplam 239 adet anket toplanmıştır. Uzun bir zaman diliminde veri toplanmıştır bu durum çalışmanın bir sınırlılığını oluştursa da zaman farklılığı katılımcılar tarafından verilen cevapların farklılaşmasına neden olmamiştır.

Türkiye Dağcılık Federasyonuna bağlı 275 dağcılık antrenörü, 719 Doğa Yürüyüş Lideri, 108 Dağ Mihmandarı vardır. Türkiye Dağcılık Federasyonu'na kayıtlı Dağcılık ve Doğa Sporları Kulübü ve Şubelerinin toplam sayısı 450'dir (Türkiye Dağcılık Federasyonu, 2021). Çalışmada örneklem sayısını belirlemek için G*Power 3.1 programı kullanılmıştır. Bu program yüzde 95 güven aralığında 110 anketin yeterli olacağ1$\mathrm{n}$ belirtmektedir (Test family: $\mathrm{t}$ tests, Statistical test: Linear bivariate regression: Two groups, difference between intercepts) (Faul, Erdfelder,
Lang ve Buchner 2007). Ayrica Krejcie ve Morgan (1970), 800 kişilik bir popülasyon için 260 katılımcının yüzde 95 güven aralığı ile yeterli olduğunu belirtmektedir. Ancak bu çalışmada 239 adet anket toplanabilmiştir. Bu durum çalışmanın bir diğer sınırlılığını oluşturmaktadır. Toplanan verilere istatistiksel analizler, paralel test, açılayıcı faktör analizi, korelasyon ve regresyon analizleri yapılmıştır.

\section{ANALIZ VE BULGULAR}

\section{Çalışmanın Katılımcıları}

Çalışma katılımcılarının büyük çoğunluğunu erkekler, lisans mezunu ve 18-50 yaş aralığındaki bireyler oluşturmaktadır. Ayrıca katılımcıların önemli çoğunluğu doğa yürüyüşlerinde bir yıldır veya altı yıl ve üzerinde liderlik yapan bireylerdir. Doğa yürüyüşlerinde liderlik yapan ve bu çalışmaya katılan bireylerin aylık gelirleri 4000 TL'nin üzerindedir. Katılımcıların profili Tablo 1'de gösterilmektedir.

\section{Açıklayıcı Faktör Analizi (AFA)}

Çalışmanın bulgular kısmında katılımcıların profili incelendikten sonra kullanılan ölçeklere açıklayıcı faktör analizi yapılmıştır. Açıklayıcı faktör analizi yapılmasının önemli bir nedeni bu ölçeklerin doğa yürüyüşleri veya serbest zaman aktivitelerine katılanlar üzerinde yeterince test edilmemiş olmasıdır. Açıklayıcı faktör analizinde ölçeklerin kaç faktörlü yapıda olduklarını belirlemek amaciyla Horn'un (1965) paralel testi kullanılmıştır. Paralel test, öz-liderlik ölçeğinin dokuz, duygusal zekâ ölçeğinin üç faktörlü yapıda olduğunu ortaya çıkarmıştır. Bu nedenle açıklayıcı faktör analizinde öz-liderlik ölçeği dokuz, duygusal zekâ ölçeği de üç faktör ile sınırlandırılmıştır. İki ölçeğe de faktör çıkarım yöntemi olarak temel bileşenler faktör analizi, döndürme yöntemi olarak varimax kullanılmıştır (Hair, Black, Babin ve Anderson 2014; Tabachnick ve Fidell 2015).

Bu güncel çalışmadaki açıklayıcı faktör analizi sonucunda öz-liderlik ölçeğinin 27 ifade ve dokuz faktörlü bir yapıda olduğu sonucuna ulaşılmıştır. Bu açıdan bakıldığında elde edilen so- 
Tablo 1. Katılımcıların Profili

\begin{tabular}{|c|c|c|c|c|c|}
\hline Cinsiyet & (n) & $\%$ & Liderlik Yılı & (n) & $\%$ \\
\hline Kadın & 78 & 32,6 & 1 & 57 & 23,8 \\
\hline Erkek & 161 & 67,4 & 2 & 22 & 9,2 \\
\hline Toplam & 239 & 100,0 & 3 & 22 & 9,2 \\
\hline Eğitim & (n) & $\%$ & 4 & 25 & 10,5 \\
\hline Lise & 33 & 13,8 & 5 & 27 & 11,3 \\
\hline Lisans & 164 & 68,6 & 6 ve üzeri & 86 & 36,0 \\
\hline Lisansüstü & 42 & 17,6 & Toplam & 239 & 100,0 \\
\hline Toplam & 239 & 100,0 & & & \\
\hline Yaş & (n) & $\%$ & Gelir Durumu & (n) & $\%$ \\
\hline $18-30$ & 79 & 33,1 & 2000 TL ve altı & 42 & 17,6 \\
\hline $31-40$ & 84 & 35,1 & $2000-4000 \mathrm{TL}$ & 40 & 16,7 \\
\hline $41-50$ & 50 & 20,9 & 4000 TL ve üzeri & 157 & 65,7 \\
\hline 51 ve üzeri & 26 & 10,9 & Toplam & 239 & 100,0 \\
\hline Toplam & 239 & 100,0 & & & \\
\hline
\end{tabular}

nuçlar, ölçeğin geçerliğinin ve güvenirliğinin sağlandığı çalışmalardaki faktör yapısıyla benzerdir. Doğan ve Şahin (2008) öz-liderlik ölçeğini 34 ifade ve dokuz faktör olarak, Houghton ve Neck (2002) öz-liderlik ölçeğini 35 ifade ve dokuz faktör olarak, Konan ve Atik (2015) öz-liderlik ölçeğini 29 ifade ve dokuz faktör olarak geçerlik ve güvenirliklerini sağlamıştır. Ayrıca öz-liderlik ölçeğinin açılanan toplam varyansı 65,9 olarak bulunmuştur. Bu değer Hair ve arkadaşlarına (2014) göre istenilen düzeyin (yüzde 50) üzerindedir.

Ölçeğin yapı geçerliği için gerekli olan Kaiser Mayer Olkin (KMO) değeri 77 olarak bulunmuştur. Kaiser' in (1974) KMO için yaptığı sınıflandırmaya göre bu değer orta hallidir (middling). Ayrıca ölçeğin güvenirlik ölçütlerinden biri olarak kullanilan Cronbach alfa değeri $(\alpha) 82$ olarak bulunmuştur. Bu değer, güvenilirlik için yeterli düzeyin (yüzde 70) üzerindedir (Hair vd. 2014). Ölçek faktörlerinin güvenirliği Tablo 2'de gösterilmektedir.

Öz-liderlik ölçeğinin faktör yüklerinin sınırını belirlemek amaciyla Norman ve Streiner'in (1998) formülü kullanılmıştır $(x=5,152 / \sqrt{ }$ (N2)). Bu formül, ,34'ün üzerindeki ifadelerin çalışmanın dışında bırakılmaması gerektiğini göstermektedir. Ancak ölçekte faktör yükü istenilen düzeyin altında olan "Önemli görevleri daha iyi gerçekleştirmek için hayal gücümü kullanırım", "Düşük performans gösterdiğimde kendimi sorgularım", "Kendim için belirlediğim amaçlarımı gerçekleştirmeye çalışırım”, "Seçme şansım olduğunda, doğa yürüyüşlerini sadece tamamlamaya çalışmaktansa hoşlandığım biçimde yapmaya çalışırım”, "Gelecekte ulaşmak istedi- 
Tablo 2. Faktör yükleri, Öz Değer, Açıklanan Varyans, Ortalama: Öz-Liderlik Ölçeği İçin AFA

\begin{tabular}{|c|c|c|c|c|c|}
\hline Faktörler & $\begin{array}{l}\text { Faktör } \\
\text { Yükü }\end{array}$ & $\begin{array}{l}\text { Öz } \\
\text { Değer }\end{array}$ & $\begin{array}{l}\text { Açılanan } \\
\text { Varyans }\end{array}$ & Ortalama & $\alpha$ \\
\hline Faktör 1: Kendi Kendine Konuşma & & 5,286 & 19,579 & 3,63 & 87 \\
\hline $\begin{array}{l}\text { Zor durumları ayrıntılı olarak değerlendirirken bazen (sesli veya } \\
\text { düşünsel olarak) kendi kendimle konuşurum }\end{array}$ & 863 & & & 3,65 & \\
\hline $\begin{array}{l}\text { Zor durumda kaldığımda sorunun üstesinden gelebilmek için bazen } \\
\text { (sesli veya düşünsel olarak) kendi kendimle konuşurum }\end{array}$ & 852 & & & 3,64 & \\
\hline $\begin{array}{l}\text { Çok zor sorunlarla yüz yüze geldiğimde bazen (sesli veya düşünsel } \\
\text { olarak) kendi kendimle konuşurum }\end{array}$ & 851 & & & 3,61 & \\
\hline Faktör 2: Başarılı Performans Hayal Etme & & 2,635 & 9,758 & 4,06 & ,71 \\
\hline $\begin{array}{l}\text { Bir işi yapmadan önce o işi başarılı bir şekilde yaptığımı zihnimde } \\
\text { canlandırıım }\end{array}$ & 802 & & & 4,10 & \\
\hline Karşılaştığım güçlüklerin üstesinden geldiğimi zihnimde canlandırııım & ,605 & & & 4,07 & \\
\hline $\begin{array}{l}\text { Bazen, bir işi yapmaya başlamadan önce kendimi o işte başarılı bir } \\
\text { performans göstermiş olarak hayal ederim }\end{array}$ & 604 & & & 3,93 & \\
\hline $\begin{array}{l}\text { Bir zorlukla karşılaştığımda, önce onun üstesinden nasıl geleceğimi } \\
\text { zihnimde canlandırırım }\end{array}$ & ,571 & & & 4,15 & \\
\hline Faktör 3: Kendini Ödüllendirme & & 2,045 & 7,575 & 3,61 & ,77 \\
\hline $\begin{array}{l}\text { Bir görevi başarıyla yerine getirdiğimde, genellikle hoşlandığım bir } \\
\text { şeyle kendimi ödüllendiririm }\end{array}$ & 819 & & & 3,61 & \\
\hline $\begin{array}{l}\text { İyi bir şey yaptığımda kendimi güzel bir akşam yemeği sinema alışveriş̧ } \\
\text { gezi gibi özel bir şeyle ödüllendiririm }\end{array}$ & ,785 & & & 3,44 & \\
\hline $\begin{array}{l}\text { Bir görevin gereğini iyi bir şekilde yaptı̆ı̆ımda çok hoşuma giden bir } \\
\text { şeyi yaparak kendimi ödüllendiririm }\end{array}$ & ,742 & & & 3,79 & \\
\hline Faktör 4: Kendini Gözlemleme & & 1,600 & 5,927 & 4,29 & ,62 \\
\hline İşimi ne kadar iyi yaptı̆̆ıma dikkat ederim & ,730 & & & 4,34 & \\
\hline $\begin{array}{l}\text { Bir etkinlikte bulunurken bunu ne kadar iyi yaptığımın genellikle } \\
\text { farkındayım }\end{array}$ & ,655 & & & 4,30 & \\
\hline Ne kadar başarılı olduğuma ilişkin öz değerlendirme yaparım & 640 & & & 4,25 & \\
\hline Faktör 5: Kendini Cezalandırma & & 1,549 & 5,735 & 3,75 & ,65 \\
\hline Bir işi iyi yapmadığımda kendimi suçlu hissederim & 800 & & & 3,72 & \\
\hline $\begin{array}{l}\text { Bir işi iyi yapmadığımda kendimi sert biçimde değerlendirme } \\
\text { eğilimindeyim }\end{array}$ & ,768 & & & 3,59 & \\
\hline $\begin{array}{l}\text { Bir işi iyi yapmadığımda kendime ilişkin hoşnutsuzluğumu açıkça ifade } \\
\text { ederim }\end{array}$ &, 565 & & & 3,96 & \\
\hline Faktör 6: Düşünce/Varsayımları Değerlendirme & & 1,387 & 5,138 & 4,09 & ,57 \\
\hline $\begin{array}{l}\text { Zor bir durumla karşılaştığımda kendi düşünce ve ön kabullerimi } \\
\text { dikkate alarak durumu değerlendiririm }\end{array}$ & 689 & & & 4,08 & \\
\hline $\begin{array}{l}\text { Bir sorunla karşılaştığımda bu duruma ilişkin düşüncelerimin } \\
\text { doğruluğunu zihnimde değerlendirmeye çaba gösteririm }\end{array}$ & ,671 & & & 4,23 & \\
\hline $\begin{array}{l}\text { Herhangi biriyle anlaşmazlık yaşadığımda kendi görüşlerimi yeniden } \\
\text { değerlendirir ve gözden geçiririm }\end{array}$ &, 575 & & & 3,97 & \\
\hline Faktör 7: İpuçları & & 1,159 & 4,292 & 3,79 & ,79 \\
\hline Yapmam gerekenleri hatırlamak için yazılı notlar kullanırım & 866 & & & 3,77 & \\
\hline $\begin{array}{l}\text { Yapmam gerekenlere odaklanmama yardımcı olması için somut } \\
\text { hatırlatıcılar (notlar, listeler vb.) kullanırım }\end{array}$ & 819 & & & 3,81 & \\
\hline Faktör 8: Doğal Ödüller Üzerine Düşünceyi Odaklama & & 1,120 & 4,147 & 3,64 &, 50 \\
\hline Bir işi yapmanın kendime özgü yollarını bulurum & ,660 & & & 4,19 & \\
\hline $\begin{array}{l}\text { Çevremi benden beklenilenleri yerine getirmemesi sağlayabilecek } \\
\text { nesne ve kişilerden oluştururum }\end{array}$ & ,492 & & & 2,87 & \\
\hline $\begin{array}{l}\text { Düşüncemi doğa yürüyüşlerindeki etkinliklerimin olumsuz } \\
\text { yanlarından çok olumlu yanlarına odaklarım }\end{array}$ & 469 & & & 3,89 & \\
\hline Faktör 9: Hedef Belirleme & & 1,020 & 3,778 & 4,25 &, 57 \\
\hline Kendi performansımı arttırmak için özel amaçlar belirlerim & ,766 & & & 4,28 & \\
\hline Yapacaklarım için zihnimde belirgin amaçlar oluştururum & 637 & & & 4,28 & \\
\hline Kişisel başarıma yönelik, özel amaçlar belirlerim & 464 & & & 4,21 & \\
\hline Faktör çıkarım yöntemi: Temel Bileşenler & & & & & \\
\hline
\end{tabular}


Doğa Yürüyüşçülerinin Öz-Liderliklerinde Duygusal Zekânın Rolü

Tablo 3. Faktör Yükleri, Öz Değer, Açıklanan Varyans, Ortalama: Duygusal Zekâ Ölçeği İçin AFA

\begin{tabular}{|c|c|c|c|c|c|}
\hline Faktörler & $\begin{array}{l}\text { Faktör } \\
\text { Yükü }\end{array}$ & $\begin{array}{l}\ddot{Z} z \\
\text { Değer }\end{array}$ & $\begin{array}{l}\text { Açıklanan } \\
\text { Varyans }\end{array}$ & Ortalama & $\alpha$ \\
\hline Faktör 1: Öz Kontrol & & 6,127 & 34,041 & 3,58 & ,89 \\
\hline $\begin{array}{l}\text { Olayların akışına göre hayatımı düzenlemek benim için } \\
\text { genellikle zordur }\end{array}$ & 790 & & & 3,54 & \\
\hline Motivasyonumu devam ettirmekte zorlanırım & ,756 & & & 3,68 & \\
\hline Haklarımı savunmak benim için genellikle zordur & ,751 & & & 3,90 & \\
\hline Çoğu zaman hangi duyguyu hissettiğimi ayırt edemem & 742 & & & 3,66 & \\
\hline Duygularımı düzenlemekte genellikle zorlanıım & ,722 & & & 3,46 & \\
\hline $\begin{array}{l}\text { Bana çok yakın olan kişilerle bile, aramda bağ oluşturmak } \\
\text { benim için zordur }\end{array}$ & 699 & & & 3,76 & \\
\hline Sonradan pişman olacağım şeyleri yapma eğilimim vardır & ,692 & & & 3,50 & \\
\hline Verdiğim kararlarımı sıklıkla değiştirme eğilimim vardır & ,681 & & & 3,53 & \\
\hline Yakınlarıma, duygularımı göstermekte genelde zorlanırım & ,583 & & & 3,24 & \\
\hline $\begin{array}{l}\text { Tartışırken haklı olduğumu bilsem dahi, geri çekilmeye } \\
\text { meyilliyim }\end{array}$ &, 535 & & & 3,56 & \\
\hline Faktör 2: Sosyallik & & 2,137 & 11,870 & 4,11 & ,68 \\
\hline Birçok iyi özelliğe sahip olduğumu düşünüyorum & ,676 & & & 4,12 & \\
\hline $\begin{array}{l}\text { Diğer insanların duygularını bir şekilde etkileyebilme } \\
\text { yeteneğim vardır }\end{array}$ &, 647 & & & 3,96 & \\
\hline İnsanlarla etkin bir biçimde baş edebilirim & ,638 & & & 4,14 & \\
\hline Genel anlamda, yüksek motivasyonlu birisiyim & ,602 & & & 4,21 & \\
\hline Genellikle, yeni çevreye uyum sağlama yeteneğim vardır &, 572 & & & 4,17 & \\
\hline Faktör 3: Iyi Oluş & & 1,113 & 6,183 & 3,91 & 50,1 \\
\hline Genel olarak, hayatımdan memnunum & ,758 & & & 3,93 & \\
\hline $\begin{array}{l}\text { Kişisel donanımlarımın, güçlü yönlerimin tam olduğuna } \\
\text { inanıyorum }\end{array}$ &, 568 & & & 3,76 & \\
\hline Genelde stresle baş edebilirim & ,443 & & & 4,06 & \\
\hline Faktör çıkarım yöntemi: Temel Bileşenler & & & & & \\
\hline
\end{tabular}

ğim amaçlarım üzerinde düşünürüm", "Kendi düşünce ve ön kabullerim üzerine odaklanır ve onları değerlendiririm”, "Çalıştığım projelere ilişkin kendi gelişimimi izlerim" ve "Etkinliğin eğlenceli yanları arayıp bulurum" ifadeleri analizden çıkarılmıştır.

Duygusal zekâ ölçeğine yapılan açıklayıcı faktör analizinde üç faktör elde edilmiştir. Elde edi- len sonuçlar, ölçeğin geçerliğinin ve güvenirliğinin sağlandığ çalışmalardaki faktör yapısıyla farklılık göstermektedir. Bu durumun nedeninin örneklem kitlesinin farklılığından kaynaklandığ 1 düşünülmektedir. Bu ölçek serbest zaman aktivitelerine katılan bireyler üzerine ilk defa uygulanmaktadır. Deniz ve arkadaşları (2013) çalışmalarında duygusal zekâ ölçeğini iyi oluş, öz kontrol, 
duygusallık, sosyallik ve toplam duygusal zekâ olarak beş faktörlü yapı ortaya çıkarmışlardır. Petrides ve Furnham (2000) ise duygusal zekâ ölçeğini dört faktörlü bir yapıda geçerlik ve güvenirliğini sağlamışlardır. Bununla birlikte bu çalışmada duygusal zekâ ölçeğinin açıklanan toplam varyansı 52,1 olarak bulunmuştur. Bu değer Hair ve arkadaşlarına (2014) göre istenilen düzeyin (yüzde 50) üzerindedir.

Ölçeğin yapı geçerliği için gerekli olan KMO değeri 89 olarak bulunmuştur. Bu değer, Kaiser'in (1974) KMO için yaptığı sınıflandırmaya göre değerlidir (meritorious). Ayrıca ölçeğin güvenirlik ölçütlerinden biri olarak kullanılan Cronbach alfa değeri $(\alpha) 88$ olarak bulunmuştur. Bu değer, güvenilirlik için yeterli düzeyin (yüzde 70) üzerindedir (Hair vd. 2014). Ölçek faktörlerinin güvenirliği Tablo 3'te gösterilmektedir.

Duygusal zekâ ölçeğinin faktör yüklerinin s1nırını belirlemek amaciyla Norman ve Streiner' in (1998) formülü kullanılmıştır ( $x=5,152 / \sqrt{ }(\mathrm{N}-2)$ ). $\mathrm{Bu}$ formül neticesinde faktör yükü istenilen düzeyin altında olan "Sıklıkla duraksar ve hisset- tiklerimi düşünürüm." ve "Genellikle, hayatımda işlerin yolunda gideceğine inanırım." ifadeleri çalışmadan çıkarılmıştır. Ancak faktör yükü 50'nin altında olan bazı ifadeler çalışmadan çıkarılmamıştır.

\section{Korelasyon Analizi}

Faktörler arasındaki korelasyon ilişkisinde anlamlı en yüksek korelasyon, sosyallik ile iyi oluş arasındadır $(r=, 59)$. Faktörler arasındaki anlamlı en düşük korelasyon başarılı performans hayal etme ile kendini ödüllendirme arasındadır $(r=, 13)$. Ölçekler arasındaki anlamlı en yüksek korelasyon kendini gözlemleme ve sosyallik arasındadır $(r=, 43)$. Ölçekler arasındaki anlamlı en düşük korelasyon ise ipuçları ile sosyallik arasındadir $(\mathrm{r}=, 18)$.

Korelasyon analizinde kendi kendine konuşma ile iyi oluş ve kendini gözlemleme ile sosyallik arasında anlamlı pozitif yönde orta kuvvette bir korelasyon ilişkisi vardır. Diğer taraftan başarılı performans hayal etme ile kendini ödüllendirme

Tablo 4. Korelasyon Analizi

\begin{tabular}{|c|c|c|c|c|c|c|c|c|c|c|c|c|}
\hline Faktörler & 1 & 2 & 3 & 4 & 5 & 6 & 7 & 8 & 9 & 10 & 11 & 12 \\
\hline $\begin{array}{l}\text { Kendi } \quad \text { Kendine } \\
\text { Konuşma }\end{array}$ & 1 & & & & & & & & & & & \\
\hline $\begin{array}{l}\text { Başarılı Performans } \\
\text { Hayal Etme }\end{array}$ &, $16^{*}$ & 1 & & & & & & & & & & \\
\hline Kendini Ödüllendirme &, $39 * *$ & ,13* & 1 & & & & & & & & & \\
\hline Kendini Gözlemleme &,- 07 &, $35 * *$ & 01 & 1 & & & & & & & & \\
\hline Kendini Cezalandırma &, $22 * *$ & ,05 &, $31 * *$ & ,09 & 1 & & & & & & & \\
\hline $\begin{array}{l}\text { Düşünce/Varsayımları } \\
\text { Değerlendirme } \\
\end{array}$ & 01 &, $34 * *$ & 13 &, $34 * *$ & $16^{*}$ & 1 & & & & & & \\
\hline İpuçları &, $19 * *$ &, $21 * *$ &, $25 * *$ &, $17^{* *}$ &, $16^{*}$ &, $22 * *$ & 1 & & & & & \\
\hline $\begin{array}{l}\text { Doğal Ödüller Üzerine } \\
\text { Düşünceyi Odaklama }\end{array}$ &, $33 * *$ & 10 &, $30 * *$ &,- 05 &, $35 * *$ & ,06 &, $27^{* *}$ & 1 & & & & \\
\hline Hedef Belirleme &, $14^{*}$ &, $42 * *$ & ,10 &, $46 * *$ &, $15^{*}$ &, $34 * *$ &, $27^{* *}$ &, $16^{*}$ & 1 & & & \\
\hline Öz Kontrol &,- 07 & ,05 & 11 & ,04 & ,04 &, $24 * *$ & 07 & ,07 & 11 & 1 & & \\
\hline Sosyallik & ,06 &, $37 * *$ & ,08 &, $43^{* *}$ & ,09 &, $39 * *$ &, $18^{* *}$ & ,11 &, $37 * *$ &, $31 * *$ & 1 & \\
\hline İyi Oluş &,- 07 &, $29 * *$ & ,07 &, $28 * *$ & ,04 &, $34 * *$ & ,12 & ,05 &, $25 * *$ & $37 * *$ &, $59 * *$ & 1 \\
\hline Standart sapma & ,89 & ,61 & ,81 & ,57 & ,69 & ,61 & 87 & ,67 & ,50 & ,71 & ,53 & ,55 \\
\hline
\end{tabular}

50 - Anatolia: Turizm Araştırmaları Dergisi 


\begin{tabular}{lccc}
\hline Faktörler & $\begin{array}{l}\text { Standardize edilmiş Beta } \\
(6)\end{array}$ & Sig. \\
\hline İyi Oluş &, 36 & 5,497 & $p=, 001$ \\
\hline Sosyallik &, 20 & 2,497 & $p=, 004$ \\
\hline Öz-kontrol &,- 11 & $-2,574$ & $p=, 011$ \\
\hline
\end{tabular}

Not: Çoklu R: ,51; R Kare: ,25; Uyarlanmış R Kare: ,25; F: 26,35; Signif F <,05

ve ipuçları ile sosyallik arasında anlamlı pozitif yönde zayıf kuvvette bir korelasyon ilişkisi vardır.

\section{Regresyon Analizi}

Çalışmada regresyon analizi duygusal zekânın öz-liderlik üzerindeki etkisini tespit etmek için yapılmıştır. Öz-liderlik ölçeği çalışmanın bağım$l_{1}$ değişkenidir ve tek bir faktör haline getirilerek analiz edilmiştir. Alanyazındaki bazı araştırmalarda öz-liderlik ölçeği üç temel değişken çerçevesinde (Doğal odaklı, davranış odaklı ve ödül odaklı stratejiler) analiz edilmiştir (Uğurluoğlu 2010; Göksoy, Emen ve Yenipınar 2014). Diğer taraftan Furtner ve arkadaşları (2010), öz-liderlik ölçeğini tek faktör haline alarak da analiz etmiştir. Bu güncel çalışmada da öz-liderlik ölçeğinin tek faktör haline getirilerek analiz edilmesinin daha doğru sonuçlar vereceği düşünüldüğünden tek faktör haline getirilerek analiz edilmiştir.

Regresyon analizinde elde edilen sonuçlara göre doğa yürüyüşçülerinin öz-liderliklerinde duygusal zekânın etkili olduğu bulunmuştur. Doğa yürüyüş̧̧ülerinin duygusal zekâlarının özliderlikleri üzerinde etkili olan ilk değişken iyi oluş olarak ortaya çıkmıştır ( $p=, 001$ ve $\beta=, 36)$. Daha sonra öz-liderliği sırasıyla sosyallik ( $\mathrm{p}=, 004$ ve $\beta=, 20)$ ve öz-kontrol $(p=, 011$ ve $\beta=-, 11)$ değişkenlerinin etkilediği belirlenmiştir. Bu model, genel olarak doğa yürüyüşçülerinin öz-liderlikleri üzerinde duygusal zekânın etkisini ,36 oranında açıklamaktadır $(\mathrm{R} 2=, 25)$. Bu nedenle bu model, geniş bir etkiye sahiptir (Cohen 1988). Modelde hataların bağımsızlığını test etmek için Durbin-
Watson istatistiği hesaplanmıştır $(1,73)$. Bu rakam kabul edilebilir bir seviyededir.

Yapısal model, duygusal zekâ değişkenlerinin doğa yürüyüşçülerinin öz-liderlikleri üzerindeki etkisini göstermektedir. İyi oluş ve sosyallik doğa yürüyüşçülerinin öz-liderliklerini pozitif yönde, öz-kontrollerini negatif yönde açılamaktadır. Bu durum öz-kontrolün doğa yürüyüşçülerinin öz-liderlikleri üzerinde ters bir etkiye sahip olduğu anlamına gelmektedir.

Furtner ve arkadaşları (2010), pek çok yönden duygusal zekânın öz-liderlik üzerinde önemli ölçüde pozitif etkileri olduğu sonucuna ulaşmiştır. Liderlerin duygusal kontrol ile ilişkili olmayabilecek düşünce ve davranış kalıplarını düzenlemede duygusal zekânın etkili olduğunu

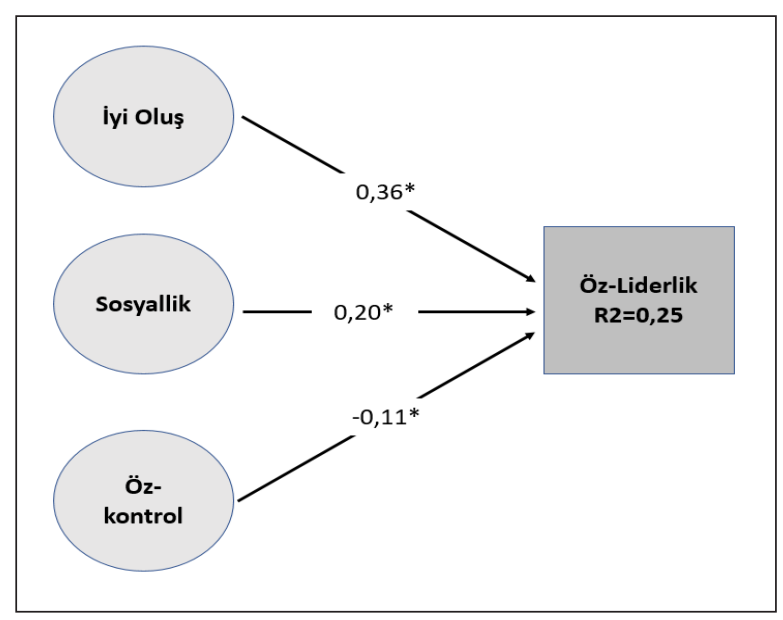

$*(\mathrm{P}<0,05)$

Şekil 1. Yapisal Model 
da ortaya koymuşlardır (Furtner ve arkadaşla$\mathrm{rl}, 2010)$. Bu güncel çalışmada da benzer şekilde duygusal zekânın kontrol üzerinde ters bir etkisi olduğu sonucuna ulaşılmıştır. Maamari ve Majdalani (2017), yüksek duygusal zekânın liderlerin iletişimleri, performansları, istikrarları, sosyal ilişkileri, empati düzeyleri, karar verme düzeyleri ve verimlilikleri üzerinde pozitif yönde etkili olduğunu bulmuştur. Ayrıca kişinin duygusal zekâsının etkili ve başarılı bir liderliğin temel belirleyicisi olduğu sonucuna ulaşılmıştır (George 2000; D’Intino vd. 2007; Alotaibi, Amin ve Winterton 2020).

\section{TARTIŞMA VE SONUÇ}

Doğa yürüyüşlerinde liderlik yapan bireylerin duygu ve davranışları öz-liderlikleri üzerinde etkilidir ve bu aktiviteyi birlikte yaptıkları kişilerin motivasyonunu da etkileyebilmektedir. Ayrica liderlerin bu aktivitelerde duygularını yönetebilmesinde ve sosyal ilişkiler kurmasında duygusal zekâ önemli bir rol oynamaktadır (Prati vd. 2003; D'Intino vd. 2007). Bu güncel çalışmada da duygusal zekâ ile öz-liderlik arasında pozitif yönde ilişki olduğu tespit edilmiştir. Doğa yürüyüşlerinde liderlik yapan bireylerin öz-liderliğin davranış odaklı stratejilerini örneğin; işlerini dikkatli yapmak, işlerini iyi yapmak için özen göstermek ve öz değerlendirme yapabilmek gibi davranışlarda duygusal zekâlarının etkili olduğu ortaya çıkmıştır. Vann, Sparks ve Baker (2017) da duygusal zekânın liderlerin hedef belirleme ve kendini gözlemleme gibi davranış odaklı stratejileri ortaya çıkarmada yardımcı olduğunu belirtmektedir. Gartner ve Stough (2002) duygusal zekâsı yüksek liderlerin grup üyelerinin performanslarını daha fazla arttırdıklarına ulaşmıştır. Bu güncel çalışma ayrıca alanyazından farklı olarak rekreatif aktivitelerde liderlik yapan bireylerin duygusal zekâlarının öz-liderlikleri üzerinde etkili olduğunu da ortaya koymuştur.

Doğa yürüyüşü aktivitelerinde sosyal ve motive olan ve aktivite grubundaki diğer kişileri de motive etme konusunda sıkıntı yaşamayan liderlerin aynı zamanda aktivite grubuna daha dikkatli liderlik yaptıkları sonucuna ulaşılmıştır. Benzer şekilde Batool (2013), liderlerin akranları- na göre daha iyi performans göstermelerini sağlayan duygusal zekânın teknik becerilerine daha fazla hâkim olduklarını belirtmektedir. Maamari ve Majdalani (2017) duygusal zekânın ayrıca liderlik tarzını da etkileyebileceği sonucuna ulaşmıştır. Bu güncel çalışmada ise doğa yürüyüşlerinde güvenliğin ön planda olmasından dolayı doğa yürüyüşü liderlerinin liderlik tarzlarında güvenlik ön plandadır. Bu nedenle doğa yürüyüşü aktivitelerinde liderlerin güvenlik endişeleri yeni yaklaşımları denemek yerine bilindik yolları ve yöntemleri denemelerine neden olmaktadır. Bununla birlikte duygusal zekâ doğa yürüyüşü liderlerinin aktiviteyi birlikte yaptıkları kişilere karşı daha duyarlı davranmasına olanak tanımaktadır. Aktivite sırasında ortaya çıkabilecek bir soruna karşı duygusal zekâsı yüksek liderler soğukkanlılıkla sorunu çözme ve etkili iletişim kurma yeteneklerine de sahiptir. Benzer şekilde Hayashi ve Ewert (2006) duygusal zekânın, içsel ve kişilerarası özellikte olduğunu ve alan dışı aktivitelerde liderlik ile pozitif yönde ilişkili olduğunu ortaya çıkarmıştır.

Doğa yürüyüşlerinde liderlik yapan bireyler hayatlarından memnun, kişisel donanımları güçlü ve stres ile baş edebilir durumdadır. Ayrıca liderler, insanların duygularını etkileyebilme yeteneğine sahip, yüksek motivasyonlu ve çevresine uyum sağlayan bireylerdir. Bu özelliklerinden dolayı liderler, duygusal zekâları yüksek bireylerdir ve bu özellikler onların öz-liderlikleri üzerinde de olumlu etkiler sağlamaktadır. Diğer taraftan duygusal zekâ ölçeğinin bir boyutu olan öz-kontrol, doğa yürüyüşlerinde liderlik yapan bireylerin öz-liderliklerini ters yönde etkilemektedir. Bunun anlamı liderler, aktivite sırasında duygularını düzenlemekte, duygularını kolaylıkla göstermekte ve verdikleri kararlarda kendilerine güvenmektedir. Bu nedenle yüksek bir duygusal zekâya sahip olmanın doğa yürüyüşlerinde liderlik yapan bireylerin liderlik özelliklerini daha iyi gösterebildikleri sonucuna ulaşılmıştır. Daha yüksek bir duygusal zekâya sahip doğa yürüyüşü lideri, aktivite sırasında olumlu duygu ve düşünce sergileme eğilimindedir. Çalışma bu açıdan D'Intino ve arkadaşları (2007) ve Maamari ve Majdalani (2017) çalışmalarıyla benzerlikler taşımaktadır. 
Aktivite katılımcılarının doğa yürüyüşlerindeki deneyimleri, yürüyüş parkurunun zorluk derecesi, hava şartları, teknolojik ve teknik malzeme yeterliliği, grup üyelerinin birbirini tanıma süresi, katılımcıların yaş ortalaması, lider ile artçının uyumu gibi etkenler liderin grup ile etkileşimini pozitif ya da negatif olarak etkilemektedir. Ayrıca doğa yürüyüşü liderlik aktivitelerinin büyük bölümü dağcılık kulüpleri aracılığıyla gerçekleştirilmektedir. Kulüplerde aktivite liderlerinin seçimi yapılmadan önce, liderlerin kulüp içi seçiminde kıstasların belirlenmesi ve sosyal iletişim becerilerinin geliştirilmesine yönelik eğitimler verilmesi duygusal zekânın liderler üzerinde gelişimine katkı sağlayacak ve aktivitelerin kalitesini arttıracaktır.

Çalışma, doğa yürüyüşü liderlerinin duygusal zekâsının öz-liderlik davranışlarında etkili bir faktör olduğuna dair teorik öngörüyü doğrulamıştır. Alanyazında duygusal zekâ ile öz-liderlik arasındaki ilişkiyi inceleyen çalışmalar olmasına rağmen bu ilişki serbest zaman ve rekreasyon çalışmalarında yeterince tanımlanmamıştır. Bu güncel çalışma sonucunda duygusal zekâ ile öz-liderlik arasında ortaya çıkan bu ilişki, iki değişken dikkate aldığında serbest zaman çalışmalarına yeni bir bakış açısı kazandıracaktır. Ayrıca bu güncel çalışma doğa yürüyüşü liderleri için gerekli olan duygusal zekâ düzeyinin teorik modeline duyulan ihtiyaca yer vermekle birlikte serbest zaman aktivite katılımclarının sosyal psikoloji konularıyla birlikte ele alınacağı çalışmalara da katkılar sunmaktadır.

Her çalışmada olduğu gibi bu çalışmanın da s1nırlılıkları vardır. İlk olarak, çalışmada katılımcılar arasında demografik ve bölgesel farklılıkları incelenmemiştir. İkinci olarak, öz-liderlik ölçeği 35 ifadeden oluşmaktadır. Ancak bu çalışmada 29 ifadeli bir yapı ortaya çıkmıştır. Bu ölçeğin ileriki çalışmalarda sadeleştirilmesi önerilmektedir. Birbirine benzer ifadelerin çalışmadan çıkarılarak net ve sade bir yapıda öz-liderlik ölçeğinin geliştirilmesi alanyazına katkı sağlayacaktır. Son olarak çalışma, Türkiye Dağcılık Federasyonu tarafından verilen dağ mihmandarlığı, dağcılık antrenörlüğü, yaz ve kış doğa yürüyüş liderliği belgesi olan ve kulüplerinde eğitim almış kişile- re yapılmıştır. Doğa Koruma ve Milli Parklar Genel Müdürlügü yetkisinde olan alan kılavuzları ve Turizm Amaçlı Sportif Faaliyetler Yönetmeliği kapsamında yapılan aktivitelerde liderlik yapanlar çalışmada yer almamıştır. Doğa yürüyüşlerinde liderlik yapan bireyler ayrıca bu aktiviteyi bazı bölgelerde gezi turları haline getirdiği görülmektedir. Ancak bu çalışmada bu konuya da yer verilmemiştir.

\section{KAYNAKÇA}

Abdullahi, A. Z., Anarfo, E. B. ve Anyigba, H. (2020). The Impact of Leadership Style on Organizational Citizenship Behavior: Does Leaders' Emotional Intelligence Play a Moderating Role?, Journal of Management Development, 39 (9/10): 963-987.

Acebes-Sánchez, J., Diez-Vega, I., Esteban-Gonzalo, S. ve Rodriguez-Romo, G. (2019). Physical Activity and Emotional Intelligence among Undergraduate Students: A Correlational Study, BMC Public Health, 19 (1): 1-7.

Alotaibi, S. M., Amin, M. ve Winterton, J. (2020). Does Emotional Intelligence and Empowering Leadership Affect Psychological Empowerment and Work Engagement?, Leadership \& Organization Development Journal, 41 (8): 971-991.

Barbuto, J. E. ve Burbach, M. E. (2006). The Emotional Intelligence of Transformational Leaders: A Field Study of Elected Officials, The Journal of Social Psychology, 146 (1): 51-64.

Batool, B. F. (2013). Emotional Intelligence and Effective Leadership, Journal of Business Studies Quarterly, 4 (3): 84-94.

Chan, J. T. ve Mallett, C. J. (2011). The Value of Emotional Intelligence for High Performance Coaching, International Journal of Sports Science \& Coaching, 6 (3): 315-328.

Cohen, J. (1988). Statistical Power Analysis for the Behavioral Sciences. Mahwah: Lawrence Erlbaum.

Deniz, M. E., Özer, E. ve Işık, E. (2013). Duygusal Zekâ Özelliği Ölçeği-Kısa Formu: Geçerlik ve Güvenirlik Çalışmas1, Eğitim ve Bilim, 38 (169): 407-419.

D'Intino, R. S., Goldsby, M. G., Houghton, J. D. ve Neck, C. P. (2007). Self-Leadership: A Process for Entrepreneurial Success, Journal of Leadership \& Organizational Studies, 13 (4): 105-120.

Doğan, S. ve Şahin, F. (2008). Kendi Kendine Liderlik Ölçeğinin Türkçe Uyarlaması, Geçerlilik ve Güvenilirlik Çalışması, Hacettepe Üniversitesi İktisadi ve İdari Bilimler Fakültesi Dergisi, 26 (1): 139-164.

Faul, F., Erdfelder, E., Lang, A. G. ve Buchner, A. (2007). G*Power 3: A Flexible Statistical Power Analysis Program for the Social, Behavioral, and Biomedical Sciences, Behavior Research Methods, 39 (2): 175-191.

Feldman, D. A. (1999). The Handbook of Emotionally Intelligent Leadership: Inspiring others to Achieve Results. Falls Church: Leadership Performance Solutions Press. 
Furtner, M. R., Rauthmann, J. F. ve Sachse, P. (2010). The Socioemotionally Intelligent Self-Leader: Examining Relations between Self-Leadership and Socioemotional Intelligence, Social Behavior and Personality: an International Journal, 38 (9): 1191-1196.

Gardner, L. ve Stough, C. (2002). Examining the Relationship Between Leadership and Emotional Intelligence in Senior Level Managers, Leadership \& Organization Development Journal, 23 (2): 68-78.

George, J. M. (2000). Emotions and Leadership: The Role of Emotional Intelligence, Human Relations, 53 (8): 10271055.

Göksoy, S., Engin, E. M. E. N. ve Yenipınar, Ş. (2014). Öğretmenlerin Öz Liderlik Rolleri ile Örgütsel Vatandaşlık Davranışları Arasındaki İlişkinin İncelenmesi, Kahramanmaraş Sütçü İmam Üniversitesi Sosyal Bilimler Dergisi, 11 (1): 103-116.

Hair, J. F., Black, W. C., Babin, B. J. ve Anderson, R. E. (2014). Multivariate Data Analysis (On Yedinci Bask1). Edinburg: Pearson.

Hayashi, A. ve Ewert, A. (2006). Outdoor Leaders' Emotional Intelligence and Transformational Leadership, Journal of Experiential Education, 28 (3): 222-242.

Horn, J. L. (1965). A Rationale and Test for the Number of Factors in Factor Analysis, Psychometrika, 30 (2): 179-185.

Houghton, J. D. ve Neck, C. P. (2002). The Revised Self-Leadership Questionnaire: Testing a Hierarchical Factor Structure for Self-Leadership, Journal of Managerial Psychology, 17 (8): 672-691.

Issah, M. (2018). Change Leadership: The Role of Emotional Intelligence, SAGE Open, 8 (3): 1-6.

Kaiser, H. F. (1974). An Index of Factorial Simplicity, Psychometrika, 39 (1): 31-36.

Konan, N. ve Atik, S. (2015). Kendi Kendine (Öz) Liderlik Ölçeğinin Eğitim Örgütleri için Türkçe'ye Uyarlanması, Geçerlik ve Güvenirlik Çalışması, E-International Journal of Educational Research, 6 (3): 101-115.

Krejcie, R. V. ve Morgan, D. W. (1970). Determining Sample Size for Research Activities, Educational and Psychological Measurement, 30 (3): 607-610.

Lee, Y. H. ve Chelladurai, P. (2018). Emotional Intelligence, Emotional Labor, Coach Burnout, Job Satisfaction, and Turnover Intention in Sport Leadership, European Sport Management Quarterly, 18 (4): 393-412.
Li, G. S. F., Lu, F. J. ve Wang, A. H. H. (2009). Exploring the Relationships of Physical Activity, Emotional Intelligence and Health in Taiwan College Students, Journal of Exercise Science \& Fitness, 7 (1): 55-63.

Maamari, B. E. ve Majdalani, J. F. (2017). Emotional Intelligence, Leadership Style and Organizational Climate, International Journal of Organizational Analysis, 25 (2): 327-345.

Mayer, J. D. ve Salovey, P. (1997). What is Emotional Intelligence?. İçinde D. J. Sluyter (Editör) Emotional Development and Emotional Intelligence: Educational Implications (ss. 3-34). New York: Basic Books.

Norman, G. R. ve Streiner, D. L. (1998). Biostatistics - The Bare Essentials. Hamilton: B.C. Decker Inc.

Petrides, K. V. (2009). Psychometric Properties of the Trait Emotional Intelligence Questionnaire (TEIQue). İçinde C. Stough, D. H. Saklofske ve J. D. A. Parker (Editörler) Assessing Emotional Intelligence: Theory, Research, and Applications (ss. 85-102). Londra: Springer.

Petrides, K. V. ve Furnham, A. (2000). On the Dmensional Structure of Emotional Intelligence, Personality and Individual Differences, 29 (2): 313-320.

Prati, L. M., Douglas, C., Ferris, G. R., Ammeter, A. P. ve Buckley, M. R. (2003). Emotional Intelligence, Leadership Effectiveness, and Team Outcomes, The International Journal of Organizational Analysis, 11 (3): 21-40.

Salovey, P. ve Mayer, J. D. (1990). Emotional Intelligence, Imagination, Cognition and Personality, 9 (3): 185-211.

Schutte, N. S., Malouff, J. M., Hall, L. E., Haggerty, D. J., Cooper, J. T., Golden, C. J. ve Dornheim, L. (1998). Development and Validation of a Measure of Emotional Intelligence, Personality and Individual Differences, 25 (2): 167-177.

Tabachnick, B. G. ve Fidell, L. S. (2015). Çok Değişkenli İstatistiklerin Kullanımı (Altıncı Basımdan Çeviri) (Çevirmen: Baloğlu, M.). Ankara: Nobel Yayıncilık.

Türkiye Dağcllık Federasyonu. (2021). Dağcilık, https://tdf. gov.tr/dagcilik/, Erişim tarihi: 06 Temmuz 2021.

Uğurluoğlu, Ö. (2010). Kendi Kendine Liderlik Stratejileri Üzerine Bir Araştırma, Atatürk Üniversitesi İktisadi ve İdari Bilimler Dergisi, 24 (1): 175-191.

Vann, V., Sparks, B. ve Baker, C. (2017). A Study of Emotional Intelligence and Self-Leadership, SAM Advanced Management Journal, 82 (3): 18-28. 


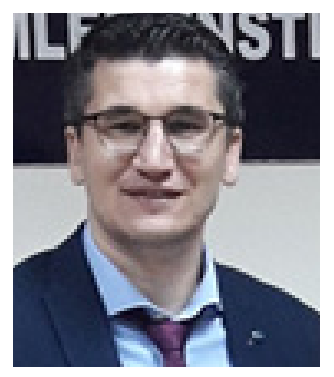

\section{Mehmet ERTAŞ}

Çukurova Üniversitesi Turizm İşletmeciliği ve Otelcilik Yüksekokulu Konaklama İşletmeciliği Bölümü'nden mezun oldu (2011). Yüksek lisans derecesini Dokuz Eylül Üniversitesi Turizm İşletmeciliği Bölümü Turizm Iş̧letmeciliği Anabilim Dalı'ndan aldı (2014). Doktora derecesini de Dokuz Eylül Üniversitesi Turizm İ̧̧letmeciliği Bölümü Turizm İşletmeciliği Anabilim Dalı'ndan aldı (2019). Pamukkale Üniversitesi'nde çalışmaya başladı (2012) ve halen Turizm Fakültesi Turizm İşletmeciliği Bölümünde görev yapmaktadır. Temel çalışma alanları; rekreasyon yönetimi ve kriz yönetimidir.

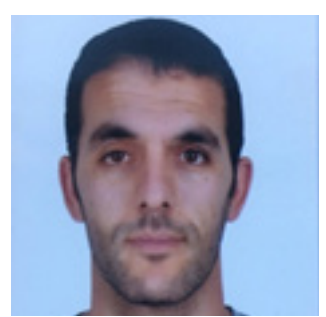

\section{Mehmet Ali IŞIK}

Dokuz Eylül Üniversitesi Buca Eğitim Fakültesi Beden Eğitimi ve Spor Öğretmenliği Bölümü’nden mezun oldu (2009). Yüksek lisans derecesini Yüzüncü YIl Üniversitesi Eğitim Bilimleri Enstitüsü Beden Eğitimi ve Spor Anabilim Dalı'ndan aldı (2019). Milli Eğitim Bakanlığı'nda Beden Eğitimi ve Spor Öğretmeni olarak çalışmaya başladı (2011) ve halen öğretmenliğe devam etmektedir. Dağcılık ve doğa sporları alanında çalışmalar yapmaktadır 